\title{
22. SOURCES OF THE SOLVENT-SOLUBLE ORGANIC MATTER IN THE GLACIAL SEQUENCE OF DSDP SAMPLES FROM THE NORWEGIAN-GREENLAND SEA, LEG 38
}

\author{
Bernd R.T. Simoneit, Organic Geochemistry Unit, School of Chemistry, \\ University of Bristol, Bristol BS8 1TS, England
}

\section{INTRODUCTION}

The Norwegian-Greenland Sea represents an excellent area for the study of ice-rafted marine sediments. The samples studied in this preliminary work are from Site 345 at the base of the Mohns Ridge in the Lofoten Basin and Site 339 on the Inner Vøring Plateau. The various other sample parameters are summarized in Table 1. Miocene sediments from Site 341 (near Site 339) were reported to have a petroliferous odor and to contain traces of oil (Talwani et al., 1975). The purpose of this investigation is to assess whether any organic matter can be ice-rafted from terrigenous sources to the marine environment and be recognizable as such. This organic matter would be derived mainly from eroded old sedimentary material and to a lesser extent from biota contemporary to the paleoenvironment.

\section{EXPERIMENTAL}

The core samples were extracted wet with Dole's mixture (isopropanol and heptane, 4:1) and then with toluene and methanol $(4: 1)$. In the case of the oily sediment $(345-4-1,130-140 \mathrm{~cm})$ methylene chloride was used after Dole's mixture. The extracts for each sample were combined then concentrated and subjected to gas chromatographic analysis (GC).

Sample 345-4-1, 130-140 cm exhibited oil (petroleum) patches on the outside and interior upon splitting. Under UV these oil patches exhibited a strong yellow fluorescence. These interior patches were sampled and extracted as indicated above. The extract was split, one portion was retained for ${ }^{13} \mathrm{C} /{ }^{12} \mathrm{C}$ analysis, and the other portion was further separated by thin-layer chromatography (TLC) using silica gel and developing with hexane and ether $(9: 1)$. The band corresponding to hydrocarbons was recovered and subjected to urea adduction. The normal and branched/cyclic fractions were analyzed by GC and gas chromatography-mass spectrometry (GC/MS).

The other sample extracts were subjected to GC and GC/MS analyses without further separation. The GC analyses were carried out on a Perkin-Elmer Model F11 gas chromatograph using a 30 meter $\times 0.5 \mathrm{~mm}$ glass capillary column coated with OV-101, programmed from $50^{\circ}-270^{\circ} \mathrm{C}$ at $4^{\circ}$ per minute and using $\mathrm{N}_{2}$ as a carrier gas. The GC/MS analyses were carried out on a DuPont Model 21-492-1 mass spectrometer interfaced with a Varian Aerograph Model 204 gas chromatograph equipped with a 10 meter $\times 0.75 \mathrm{~mm}$ glass capillary column packed with Gaschrom Q (80100 mesh) coated with $1 \%$ OV-1. The mass spectral data were acquired and processed using a DuPont Model 21094 data system.

\section{RESULTS}

Since Sample 345-4-1, 130-140 cm exhibited strong yellow fluorescence due to oil, the two other samples from Site 345 were also examined (Table 1). They did not show fluorescence. Only one additional sample (339-6-2, 140-150 cm) showed spots of yellow fluorescence. That sample is still under analysis.

The GC trace of Sample 345-4-1, 130-140 cm exhibited a Gaussian hump maximizing at the retention time of eicosane, whereas Sample 345-1-2, 130-140 cm exhibited no hump. The GC/MS data on the hump of Sample 345-4-1, 130-140 cm indicated the presence of a sterane $\left(\mathrm{C}_{n} \mathrm{H}_{2 n-6}\right.$ for $\left.n=27-29\right)$ and triterpane $\left(\mathrm{C}_{n} \mathrm{H} 2 n-8\right.$ for $n=27-32$, maximum $\left.n=30\right)$ series. Distribution diagrams of the $n$-alkanes are shown in Figure 1. Sample 345-1-2, 130-140 cm exhibited a mixed pattern of an autochthonous marine component, maximizing at $n-\mathrm{C}_{17}$ and an allochthonous terrigenous input, maximizing at $n-\mathrm{C}_{29}(\mathrm{CPI}>21=2.5)$ (Figure 1a). Sample 345-4-1, 130-140 cm exhibited an alkane distribution maximizing at $n$ - $\mathrm{C}_{20}$ and showing no odd to even predominance (Figure $1 \mathrm{~b}$ ). The $n$-alkanes in the carbon number range less than $C_{15}$ were also present. The pristane/phytane ratio was 0.3 .

\section{DISCUSSION}

The $n$-alkane distribution in Sample 345-1-2, 130-140 $\mathrm{cm}$ is analogous to other marine sediments examined (Simoneit, 1974; Simoneit and Burlingame, 1974). The maximum at $n-\mathrm{C}_{17}$ represents the marine input and the maximum at $n-\mathrm{C}_{29}$ represents the terrigenous input. This terrigenous component is typical if higher plant wax detritus (Eglinton and Hamilton, 1963), which may be of contemporary origin or of a sedimentary origin that has been recycled by ice-erosion. The lithology of the glacial sequence is quite uniform (Talwani et al., 1975), but the degree of bottom sediment redistribution at the time of deposition has not been determined. This organic matter may therefore also represent some redistributed material. Ice-rafting of eroded sedimentary kerogen from Antarctica to the Ross Sea has been demonstrated (Sackett et al., 1974). Thus, in view of the high sedimentation rates during the Plio-Pliocene in the Lofoten Basin, the probable input of the terrigenous component to this sediment was by means of icerafting.

The distribution patterns of the $n$-alkanes, the hump, and the minor steranes and triterpanes in Sample 345-4$1,130-140 \mathrm{~cm}$ are indicative of petroleum. Petroleum 
TABLE 1

DSDP Leg 38 Core Sample Descriptions

\begin{tabular}{lccclcc}
\hline $\begin{array}{c}\text { Sample } \\
\text { (Interval in cm) }\end{array}$ & Location & $\begin{array}{c}\text { Water } \\
\text { Depth } \\
(\mathrm{m})\end{array}$ & $\begin{array}{c}\text { Approx. } \\
\text { Depth Below } \\
\text { Sea Bed }(\mathrm{m})\end{array}$ & Geologic Age & $\begin{array}{c}\text { Organic } \\
\text { Carbon } \\
(\%)^{\mathrm{a}}\end{array}$ & $\begin{array}{c}\mathrm{CaCO}_{3} \\
(\%)^{\mathrm{a}}\end{array}$ \\
\hline $345-1-2,130-140$ & $69^{\circ} 50^{\prime} \mathrm{N}, 01^{\circ} 14^{\prime} \mathrm{W}$ & 3195 & 2.8 & Pleistocene & 0.28 & 25 \\
$345-4-1,130-140$ & $69^{\circ} 50^{\prime} \mathrm{N}, 01^{\circ} 14^{\prime} \mathrm{W}$ & 3195 & 28.3 & Pliocene or Pleistocene & 0.24 & 11 \\
$345-14-4,130-140$ & $69^{\circ} 50^{\prime} \mathrm{N}, 01^{\circ} 14^{\prime} \mathrm{W}$ & 3195 & 251.3 & Oligocene & 0.51 & 1.1 \\
$339-6-2,140-150$ & $67^{\circ} 13^{\prime} \mathrm{N}, 06^{\circ} 19^{\prime} \mathrm{E}$ & 1262 & 48.9 & Pleistocene & 0.64 & 7 \\
\hline
\end{tabular}

${ }^{\mathrm{a}}$ Values supplied by G. Erdman, Phillips Petroleum Company.
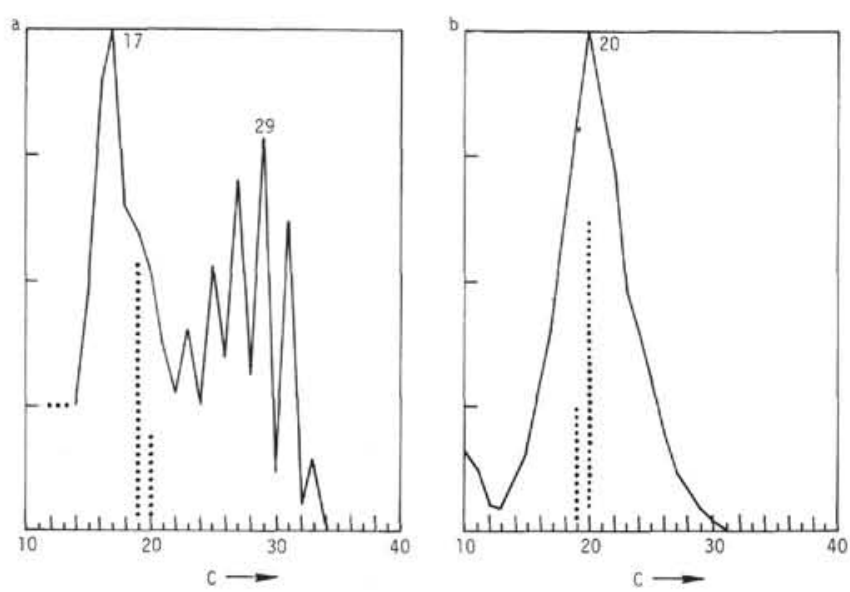

Figure 1. Distribution of n-alkanes in samples (a) 345-1-2, $130-140 \mathrm{~cm}$ and (b) $345-4-1,130-140 \mathrm{~cm} ; \ldots$ isoprenoid hydrocarbons (pristane, phytane).

was reported in Miocene sediments from Site 341 (Talwani et al., 1975). The presence of discrete droplets of petroleum in the Pliocene or Pleistocene sequence indicates that the oil migrated in as a lateral seep from below. Natural oil seeps are quite ubiquitous (Wilson et al., 1974), and the Norwegian-Greenland Sea is a very active tectonic area. The migrational seepage of this oil from a lower sedimentary source (trap) is therefore very likely. The possibility of shipboard contamination has also been examined. This oil does not compare with bearing lubricant or pipe joint grease used onboard (Simoneit et al., 1972). It also does not compare with rust inhibitor or cable grease used onboard, nor with a grease found inside the top end of core tube 22-217-21 (Simoneit, unpublished). All these potential contaminant materials have different $n$-alkane distributions and/or different maxima of the hump.

Sample 345-14-4, 130-140 cm did not exhibit a hump and had an $n$-alkane distribution consisting of about equal components of marine and terrigenous origin.

\section{CONCLUSION}

The solvent soluble organic matter in the samples from the Pleistocene and Pliocene sequence of DSDP
Site 345 has two sources. Ice-rafting appears to be the input mechanism of terrigenous organic matter to Sample $345-1-2,130-140 \mathrm{~cm}$. This type of input is completely masked in Sample 345-4-1, 130-140 cm by the overwhelming amount of petroleum. This oil has probably migrated into the unconsolidated sediment by seepage from a preglacial trap in this active tectonic environment.

\section{ACKNOWLEDGMENTS}

I thank the National Science Foundation for making the core samples available and Dr. R.P. Philp for use of laboratory facilities. Partial support from the National Aeronautics and Space Administration (NASA Grant NGL 05-003-003) is gratefully acknowledged.

\section{REFERENCES}

Eglinton, G. and Hamilton, R.J., 1963. The distribution of alkanes. In Swain, T. (Ed.), Chemical plant taxonomy: New York (Academic Press), p. 187-217.

Sackett, W.M., Poag, C.W., and Eadie, B.J., 1974. Kerogen recycling in the Ross Sea, Antarctica: Science, v. 185, p. $1045-1047$.

Simoneit, B.R., 1974. Organic analyses of Black Sea cores. In Degens, E.T. and Ross, D.A. (Eds.), The black sea-geology, chemistry, and biology: Am. Assoc. Petrol. Geol., Mem. 20, Tulsa, p. 477-498.

Simoneit, B.R.T. and Burlingame, A.L. 1974. Study of the organic matter in the DSDP (JOIDES) cores, Legs 10-15. In Tissot, B. and Bienner, F. (Eds.), Advances in organic geochemistry 1973: Paris (Editions Technip), p. 629-648.

Simoneit, B.R., Scott, E.S., Howells, W.G., and Burlingame, A.L., 1972. Preliminary organic analyses of the Deep Sea Drilling Project cores, Leg 11. In Hollister, C.D., Ewing, J.I., et al., Initial Reports of the Deep Sea Drilling Project, Volume 11: Washington (U.S. Government Printing Office), p. 1013-1045.

Talwani, M., Udintsev, G., Bjorklund, K., Caston, V.N.D., Faas, R.W., Kharin, G.N., Morris, D.A., Müller, C., Nilsen, T.H., Hinte, J.E. van, Warnke, D.A., and White, S.M., 1975. Leg 38: Geotimes, v. 20, p. 24-26.

Wilson, R.D., Monaghan, P.H., Osanik, A., Price, L.C., and Rogers, M.A., 1974. Natural marine oil seepage: Science, v. 184 , p. $857-865$. 